\title{
Determining the Break-EvenPoint for Operating in the Pension Fund of Banks
}

\author{
Donya Haji Shahvardi ${ }^{1} \&$ Mehdi Tajodini ${ }^{2}$ \\ ${ }^{1}$ Master of Accountancy Banking \\ ${ }^{2}$ Master of Accounting Banking, MA in Economics \\ Correspondence: Donya Haji Shahvardi, Master of Accountancy Banking.
}

Received: December 10, 2015

Accepted: January 10, 2016

Online Published: January 13, 2016

doi:10.5539/mas.v10n3p23

URL: http://dx.doi.org/10.5539/mas.v10n3p23

\begin{abstract}
This study is an attempt to investigate the development of actuarial science through a review on the concepts, theories and models related to actuary and its relation to pension funds and the break-evenpoint for operating in the pension fund of banksduring the financial period from 2013-2041. Furthermore, this study provides a strategy to exit the mentioned fund from the balance deficit. It is noteworthy that results indicated theresources deficit for the mentioned fund in the next three years.
\end{abstract}

Keywords: operational break-even point, actuarial, pension plans, pension funds of banks

\section{Introduction}

The problem of the pension fund is rooted in the fact that although pension plans is a long-term commitment, but it has some special features that are absent in other types of commitments. On the one hand their value are not certain, on the other hand, in many cases, companies do not know how many years they have to pay pensions to retirees. However, the payments are not ambiguous for them (Shabahang, 2008). In addition, an increase in the number of elderly people,prolongation of retirement, demographic trends, labor market recession and early retirement enhance the commitments. For this reason, long-term and medium-term effects of commitments for pension funds should be examined from the actuarial point of view.The design of a pension system in which the balance between resources and expenditure is established in the long term requires complex calculations about how to set parameters for receiving (premium rate, wages and benefits, premium payment term, etc.) and payments (age at retirement, life expectancy, pension formula and etc. ) due to economic and social factors (Behzadi, 2008). According to the notification and the adoption of Accounting Standard No. 27 (pension benefits schemes) in pension plans for trustee funds, the funds have been required to evaluate the capability to pay future commitments and insert the results in the balance sheet for usersby actuarial calculations.

\section{Literature Review}

For the first time in 1775, the actuarial term was ascribed to the English mathematician called Patterson who provided the life table for British society. In 1850, actuarial practices were used in the areas of life insurance and pension plans.In the early years of the present century, actuarial practices have been extended in new areas such as non-life insurance, medical care, social security, the financial condition of banks, and financial engineering (Roghanizadeh, 2007).

Stoner et al. (1999) conducted a study to determine the role and responsibilities of actuaries in England.In this study, according to an overview on actuary in the UK, defined contributions plans (DC) and defined benefit plans (DB) were compared, and similarities and contradictions in both plans and their advantages and disadvantages in the UK were investigated.

Gold (2003) reviewed the existing theory (transparent model) in which managers and investors consider the defined benefit plans similar to the operation of a subsidiary company and measure its value in terms of the value of the market portfolio. In addition, Gold proposed another alternative model (opaque model) in which investors and managers calculate the value of pension levels based on actuarial methods and economic assumptions and according to income.

Anantharaman (2001) conducted a study to investigatethe actuarial role and economic incentives that are faced 
in the choice of actuarial assumptions and pension plans with defined benefits. The results of this study showed that similar to situations the auditors are faced with, the risk of losing revenue from actuarial practices can affectthe choice of assumptions and distort actuarial results on the status of pension plans.

\section{Pension Plans and Its Use in Actuarial Calculations}

Pension plans are programs whereby members after termination of service receive benefits in the form of pension.

\subsection{Layers of Pension Plans}

In general, pension plans are discussed in the following three layers:

First layer: the purpose of this layer is to provide a guarantee for the minimum supports of social security for the majority or all members of society, including health care, pension, disability and survivors.

Second layer: it considers to some extent the last wageat the time of employment and pensions in the first layer.

Third layer: this method is often used by people who have more financial power at the time of employment, including individual insurance such as life insurance and savings.

\subsection{Actuarial Assumptions in Pension Plans}

The following factors have a decisive role in the actuarial calculation and are considered as the actuarial assumptions:

1) The number of employees and pensioners

2) Salaries and benefits which are subject to superannuation payment

3) Salaries and benefits calculated for pension

4) Regular and timely payment of superannuation payment for employee and employer contributions

5) Theage of pensioners and employees

6) An increase in salaries of employees and percentage of superannuation payment

7) The way to invest in the fund

8) Life expectancy

9) The level for cost of living

10) Mortality rate

In actuarial studies for pension plans, the most prominent factors include the death, retirement, and disability. When calculating the premium rate and the adjustment of costs and revenues, these factors must be considered.

\subsection{Different Methods Forthe Actuarial Prediction of Pension Funds}

In actuarial mathematics, there are different methods for predictions related to pension funds. These methods are mainly classified into three groups:

1. Absolute actuarial methods: These methods have many applications in the field of insurance.

2. Statistical and econometric models and methods: These methods include regression methods, time series analysis and statistical and econometric models.

3. Hybrid methods: Hybrid methods consider both internal and external factors.

\subsection{Resources and Expenditures for Pension Plans}

\section{Sources of income include:}

1) Insurance premiums or superannuation payment

2) Benefits of investment in long-term projects

3) Government subsidies

4) Other income includes donations, gifts and penalties arising from failure to timely payment of insurance premiums

$\checkmark$ expenditures or costs of pension plans are as follows:

5) Benefits costs (salaries and allowances)

6) Administrative costs 
One method to assess the fulfillment of the obligations of the fund is the annual assessment method. In general, there would bea fundamental principle on plans for long-term benefits. This principle is expressed in the following equation:

"The present value of expected future revenue = present value of expected future costs"

The main question is that "when is the future in this system?"The premium rate is fixed but in comparison with the rate derived from the annual assessment system, it is higher in the first years. This extension is to provide resources to invest. The major problem in the system which makes its performance ambiguous is the validity of assumptions that lead to the determination of the premium rate by actuarial calculation. This means that when the balance period is prolonged, wages and pensions may be subject to major changes because of changing social and economic conditions, and factors such as mortality rates and interest rates.

\section{Research Methodology}

Actuarial calculations are used by three assumptions, including an increase in pension, an increase in salary at the time of employment,and the rate of return on investment as well as four different modes. The resources (assets) and expenditure (commitments) of the fund are separately calculated at four modes and by different assumptions in order to calculate thebalance of resources and costs. It should be noted that the rate of increase in salaries of pensioners is $13 \%$ and $11 \%$, the rate of increase in salaries at the time of employment is $15 \%$ and $13 \%$, and the investment return rate is $17 \%$ and $15 \%$.

\section{Research Results}

In order to generalize the experiences of other countries and achieve the purpose of the use of actuarial calculations in the country, the status of pension funds of banks in 2015 is evaluated using the actuarial calculation, evaluation method at the end of the year and the annual assessment method. In cases of possible future, we assess the status of the fund. Information extracted from the Bank Pension Fund has been summarized in Table 1.

Table 1. A summary information extracted from the Bank Pension Fund

Rate of return on investment of the fund is $17 \%$ and $15 \%$ on average.

An increase in the average life of female members to the average life of male members is 3 years

An increase in the age of male employee to the age of his wife is estimated 7 years on average

Retirement date is based on 30 years of experiences or 55 years for the age of men and 50 years for women.

A deceased retired person's pension includes all pension at the time of death.

The basis for calculating salaries of the heirs (deceased at the time of employment) is similar to the calculation of pensions considering a minimum wage.

The main assumptions of the actuarial calculations in this study are:

- the exemption of investment income from income tax

- Paying the personnel costs from the surplus investment of the Fund

- Service deduction on the basis of 30 years of experience for current employees (55 years old for men and 50 years old for women)

To determine the long-term survival of the fund (break-even),its financial status is consideredby "annual assessment". In this method, the pension deductions are not included in calculations. According to data from the Bank Pension Fund, the output of every year (retirement or death) is determined based on mortality table and membership background. In other words, employees having 30 years of experiences or men at the age of 55 years old and women at the age of 50 years old as well as the deceased employees, pension is determined for them or their survivors. It is noteworthy thatdisabled, resigned and upcomingfired employeesare negligible and not included in the calculationsdue to the low probability of their leaving. Based on the following four modes, the break-evenpoint for the pension fund of banks is predicted.The results are shownin Tables 2 to 5 . 
6.1 First Mode: Predicting the Financial Status of the Fund at the End of Each Periodby the Annual Assessment Method with Three Assumptions, including an Increase in Salaries at the Time of Employment by 15\%, an Increase in Pensions by 13\%, and Return on Investment by 17\% without Considering the Beginning Inventory of the Fund

Table 2. Predicting surplus (deficit) of pension fund of banks in the first mode (Figures in Million Rials)

\begin{tabular}{|c|c|c|c|c|}
\hline $\begin{array}{l}\text { Surplus (deficit) at } \\
\text { beginning of the } \\
\text { periodwithout } \\
\text { considering the } \\
\text { beginning inventory of } \\
\text { the Fund }\end{array}$ & $\begin{array}{c}\text { Value of } \\
\text { pension } \\
\text { deductions }\end{array}$ & $\begin{array}{l}\text { Value Income of } \\
\text { Pension Fund with } \\
\text { considering } \\
\text { investment income }\end{array}$ & $\begin{array}{l}\text { Value for the received } \\
\text { deduction at the } \\
\text { beginning of the } \\
\text { period }\end{array}$ & Financial period \\
\hline$-381,033$ & 973,452 & 592,419 & 506,341 & 1392 \\
\hline$-422,529$ & $1,109,735$ & 687,206 & 587,356 & 1393 \\
\hline$-467,939$ & $1,265,098$ & 797,159 & 681,332 & 1394 \\
\hline$-517,508$ & $1,442,212$ & 924,704 & 790,346 & 1395 \\
\hline$-571,465$ & $1,644,122$ & $1,072,657$ & 916,801 & 1396 \\
\hline$-630,016$ & $1,874,299$ & $1,244,282$ & $1,063,489$ & 1397 \\
\hline$-693,333$ & $2,136,700$ & $1,443,367$ & $1,233,647$ & 1398 \\
\hline$-761,532$ & $2,435,839$ & $1,674,306$ & $1,431,031$ & 1399 \\
\hline$-834,661$ & $2,776,856$ & $1,942,195$ & $1,659,996$ & 1400 \\
\hline$-912,669$ & $3,165,616$ & $2,252,946$ & $1,925,595$ & 1401 \\
\hline$-995,384$ & $3,608,802$ & $2,613,418$ & $2,233,690$ & 1402 \\
\hline$-1,082,470$ & $4,114,034$ & $3,031,565$ & $2,591,081$ & 1403 \\
\hline$-1,173,384$ & $4,689,999$ & $3,516,615$ & $3,005,654$ & 1404 \\
\hline$-1,267,326$ & $5,346,599$ & $4,079,273$ & $3,486,558$ & 1405 \\
\hline$-1,363,166$ & $6,095,123$ & $4,731,957$ & $4,044,408$ & 1406 \\
\hline$-1,459,370$ & $6,948,440$ & $5,489,070$ & $4,691,513$ & 1407 \\
\hline$-1,553,900$ & $7,921,222$ & $6,367,322$ & $5,442,155$ & 1408 \\
\hline$-1,644,100$ & $9,030,193$ & $7,386,093$ & $6,312,900$ & 1409 \\
\hline$-1,726,552$ & $10,294,420$ & $8,567,868$ & $7,322,964$ & 1410 \\
\hline$-1,796,912$ & $11,735,638$ & $9,938,727$ & $8,494,638$ & 1411 \\
\hline$-1,849,705$ & $13,378,628$ & $11,528,923$ & $9,853,780$ & 1412 \\
\hline$-1,878,085$ & $15,251,636$ & $13,373,551$ & $11,430,385$ & 1413 \\
\hline$-1,873,546$ & $17,386,865$ & $15,513,319$ & $13,259,247$ & 1414 \\
\hline$-1,825,576$ & $19,821,026$ & $17,995,450$ & $15,380,726$ & 1415 \\
\hline$-1,721,247$ & $22,595,969$ & $20,874,722$ & $17,841,643$ & 1416 \\
\hline$-1,544,727$ & $25,759,405$ & $24,214,677$ & $20,696,305$ & 1417 \\
\hline$-1,276,696$ & $29,365,722$ & $28,089,026$ & $24,007,714$ & 1418 \\
\hline$-893,653$ & $33,476,923$ & $32,583,270$ & $27,848,949$ & 1419 \\
\hline$-5,858,911$ & $38,163,692$ & $32,304,780$ & $32,304,780$ & 1420 \\
\hline
\end{tabular}




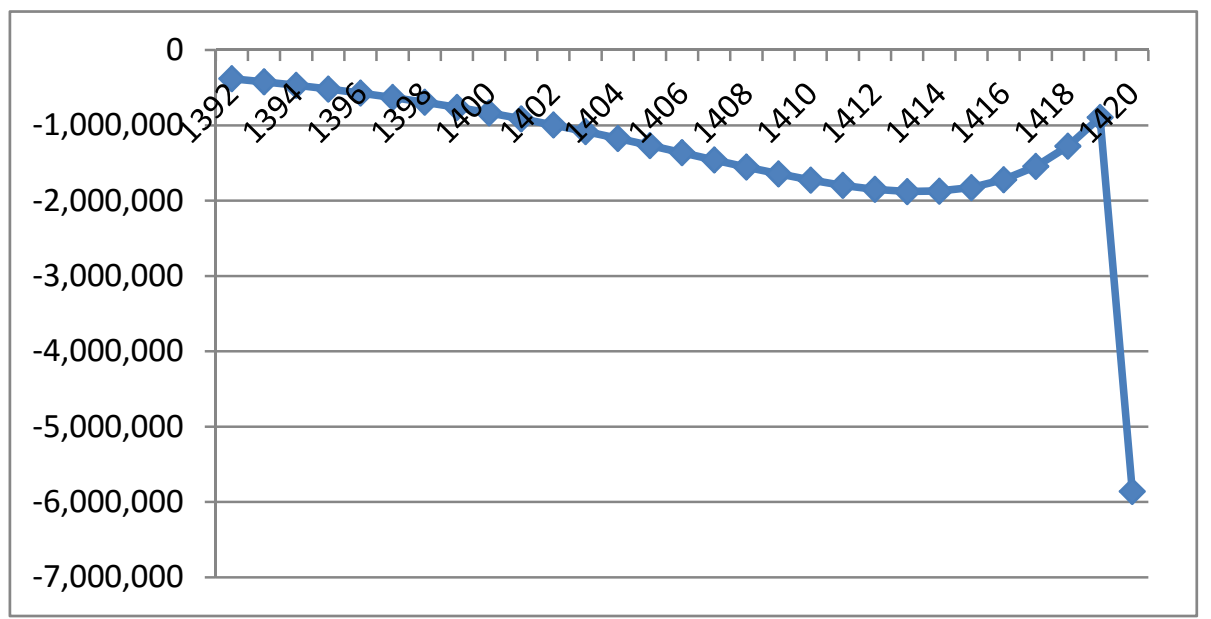

Figure 1. Predicting surplus (deficit) of pension fund of banks in the first mode

6.2 Second Mode: Predicting the Financial Status of the Fund at the End of Each Period by the Annual Assessment Method with Three Assumptions, including an Increase in Salaries at the Time of Employment by 15\%, an Increase in Pensions by 13\%, and Return on Investment by 17\% with Considering the Beginning Inventory of the Fund

Table 3. Predicting surplus (deficit) of pension fund of banks in the second mode (Figures in Million Rials)

\begin{tabular}{|c|c|c|c|c|c|}
\hline $\begin{array}{l}\text { Surplus (deficit) at } \\
\text { beginning of the } \\
\text { periodwith } \\
\text { considering the } \\
\text { beginning inventory } \\
\text { of the Fund }\end{array}$ & $\begin{array}{c}\text { Value of } \\
\text { pension } \\
\text { deductions }\end{array}$ & $\begin{array}{l}\text { Value Income of } \\
\text { Pension Fund } \\
\text { with considering } \\
\text { investment } \\
\text { income }\end{array}$ & $\begin{array}{c}\text { Value for the } \\
\text { received } \\
\text { deduction at the } \\
\text { beginning of the } \\
\text { period }\end{array}$ & $\begin{array}{l}\text { inventory of } \\
\text { fund in the } \\
\text { first period }\end{array}$ & Financial period \\
\hline $2,346,636$ & 973,452 & $3,320,088$ & 506,341 & $2,727,669$ & 1392 \\
\hline $2,323,035$ & $1,109,735$ & $3,432,770$ & 587,356 & $2,745,564$ & 1393 \\
\hline $2,250,011$ & $1,265,098$ & $3,515,110$ & 681,332 & $2,717,951$ & 1394 \\
\hline $2,115,006$ & $1,442,212$ & $3,557,218$ & 790,346 & $2,632,513$ & 1395 \\
\hline $1,903,092$ & $1,644,122$ & $3,547,214$ & 916,801 & $2,474,557$ & 1396 \\
\hline $1,596,602$ & $1,874,299$ & $3,470,900$ & $1,063,489$ & $2,226,618$ & 1397 \\
\hline $1,174,691$ & $2,136,700$ & $3,311,391$ & $1,233,647$ & $1,868,024$ & 1398 \\
\hline 612,856 & $2,435,839$ & $3,048,694$ & $1,431,031$ & $1,374,388$ & 1399 \\
\hline$-117,620$ & $2,776,856$ & $2,659,236$ & $1,659,996$ & 717,041 & 1400 \\
\hline$-1,050,284$ & $3,165,616$ & $2,115,331$ & $1,925,595$ & $-137,615$ & 1401 \\
\hline$-2,045,669$ & $3,608,802$ & $1,563,133$ & $2,233,690$ & $-1,050,284$ & 1402 \\
\hline$-3,128,138$ & $4,114,034$ & 985,896 & $2,591,081$ & $-2,045,669$ & 1403 \\
\hline$-4,301,522$ & $4,689,999$ & 388,477 & $3,005,654$ & $-3,128,138$ & 1404 \\
\hline$-5,568,848$ & $5,346,599$ & $-222,249$ & $3,486,558$ & $-4,301,522$ & 1405 \\
\hline$-6,932,013$ & $6,095,123$ & $-836,891$ & $4,044,408$ & $-5,568,848$ & 1406 \\
\hline$-8,391,383$ & $6,948,440$ & $-1,442,943$ & $4,691,513$ & $-6,932,013$ & 1407 \\
\hline$-9,945,283$ & $7,921,222$ & $-2,024,061$ & $5,442,155$ & $-8,391,383$ & 1408 \\
\hline$-11,589,383$ & $9,030,193$ & $-2,559,190$ & $6,312,900$ & $-9,945,283$ & 1409 \\
\hline$-13,315,934$ & $10,294,420$ & $-3,021,515$ & $7,322,964$ & $-11,589,383$ & 1410 \\
\hline$-15,112,846$ & $11,735,638$ & $-3,377,208$ & $8,494,638$ & $-13,315,934$ & 1411 \\
\hline$-16,962,550$ & $13,378,628$ & $-3,583,923$ & $9,853,780$ & $-15,112,846$ & 1412 \\
\hline$-18,840,635$ & $15,251,636$ & $-3,589,000$ & $11,430,385$ & $-16,962,550$ & 1413 \\
\hline$-20,714,181$ & $17,386,865$ & $-3,327,316$ & $13,259,247$ & $-18,840,635$ & 1414 \\
\hline$-22,539,757$ & $19,821,026$ & $-2,718,731$ & $15,380,726$ & $-20,714,181$ & 1415 \\
\hline$-24,261,004$ & $22,595,969$ & $-1,665,035$ & $17,841,643$ & $-22,539,757$ & 1416 \\
\hline
\end{tabular}




$\begin{array}{llclll}-25,805,731 & 25,759,405 & -46,327 & 20,696,305 & -24,261,004 & 1417 \\ -27,082,427 & 29,365,722 & 2,283,294 & 24,007,714 & -25,805,731 & 1418 \\ -27,976,080 & 33,476,923 & 5,500,843 & 27,848,949 & -27,082,427 & 1419 \\ -28,343,179 & 38,163,692 & 9,820,513 & 32,304,780 & -27,976,080 & 1420\end{array}$

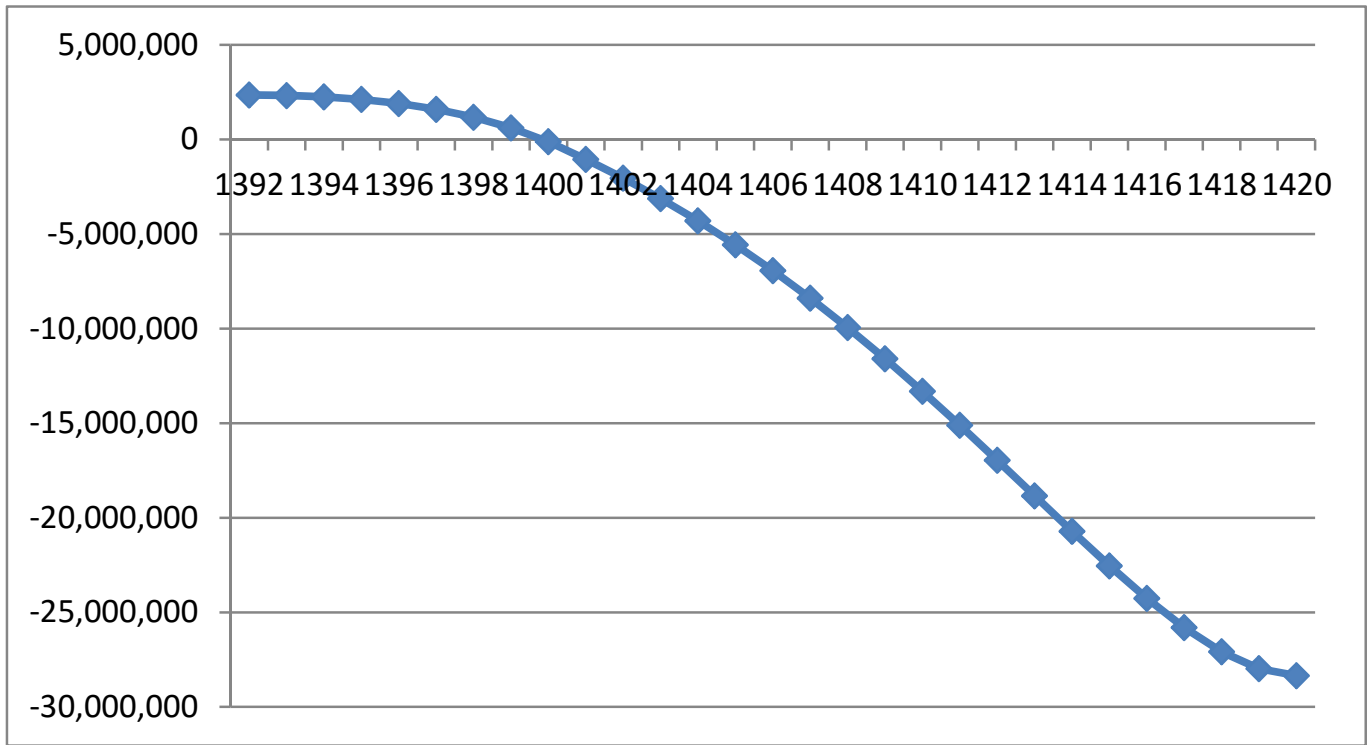

Figure 2. Predicting surplus (deficit) of pension fund of banks in the second mode

6.3 Third Mode: Predicting the Financial Status of the Fund at the End of Each Period by the Annual Assessment Method with Three Assumptions, including an Increase in Salaries at the Time of Employment by $13 \%$, an Increase in Pensions by 11\%, and Return on Investment by $15 \%$ without Considering the Beginning Inventory of the Fund

Table 4. Predicting surplus (deficit) of pension fund of banks in the third mode (Figures in Million Rials)

\begin{tabular}{ccccc}
\hline $\begin{array}{c}\text { Surplus (deficit) at beginning } \\
\text { of the periodwithout } \\
\text { considering the beginning } \\
\text { inventory of the Fund }\end{array}$ & $\begin{array}{c}\text { Value of } \\
\text { pension } \\
\text { deductions }\end{array}$ & $\begin{array}{c}\text { Value Income of } \\
\text { Pension Fund with } \\
\text { considering } \\
\text { investment income }\end{array}$ & $\begin{array}{c}\text { Value for the } \\
\text { received deduction } \\
\text { at the beginning of } \\
\text { the period }\end{array}$ & Financial period \\
\hline$-391,160$ & 973,452 & 582,292 & 506,341 & 1392 \\
$-426,453$ & $1,090,266$ & 663,813 & 577,229 & 1393 \\
$-464,351$ & $1,221,098$ & 756,747 & 658,041 & 1394 \\
$-504,939$ & $1,367,630$ & 862,691 & 750,166 & 1395 \\
$-548,277$ & $1,531,746$ & 983,468 & 855,190 & 1396 \\
$-594,401$ & $1,715,555$ & $1,121,154$ & 974,916 & 1397 \\
$-643,306$ & $1,921,422$ & $1,278,115$ & $1,111,405$ & 1398 \\
$-694,941$ & $2,151,992$ & $1,457,051$ & $1,267,001$ & 1399 \\
$-749,193$ & $2,410,231$ & $1,661,039$ & $1,444,381$ & 1400 \\
$-805,875$ & $2,699,459$ & $1,893,584$ & $1,646,595$ & 1401 \\
$-864,708$ & $3,023,394$ & $2,158,686$ & $1,877,118$ & 1402 \\
$-925,300$ & $3,386,201$ & $2,460,902$ & $2,139,915$ & 1403 \\
$-987,117$ & $3,792,546$ & $2,805,428$ & $2,439,503$ & 1404 \\
$-1,049,463$ & $4,247,651$ & $3,198,188$ & $2,781,033$ & 1405 \\
$-1,111,435$ & $4,757,369$ & $3,645,934$ & $3,170,378$ & 1406 \\
$-1,171,888$ & $5,328,254$ & $4,156,365$ & $3,614,231$ & 1407 \\
$-1,229,388$ & $5,967,644$ & $4,738,256$ & $4,120,223$ & 1408 \\
$-1,282,149$ & $6,683,761$ & $5,401,612$ & $4,697,054$ & 1409 \\
$-1,327,975$ & $7,485,813$ & $6,157,838$ & $5,354,642$ & 1410 \\
\hline
\end{tabular}




\begin{tabular}{ccccc}
\hline$-1,364,175$ & $8,384,110$ & $7,019,935$ & $6,104,292$ & 1411 \\
$-1,387,477$ & $9,390,203$ & $8,002,726$ & $6,958,892$ & 1412 \\
$-1,393,920$ & $10,517,028$ & $9,123,108$ & $7,933,137$ & 1413 \\
$-1,378,728$ & $11,779,071$ & $10,400,343$ & $9,043,777$ & 1414 \\
$-1,336,168$ & $13,192,560$ & $11,856,391$ & $10,309,905$ & 1415 \\
$-1,259,381$ & $14,775,667$ & $13,516,286$ & $11,753,292$ & 1416 \\
$-1,140,181$ & $16,548,747$ & $15,408,566$ & $13,398,753$ & 1417 \\
$-968,831$ & $18,534,596$ & $17,565,765$ & $15,274,578$ & 1418 \\
$-733,776$ & $20,758,748$ & $20,024,972$ & $17,413,019$ & 1419 \\
$-421,329$ & $23,249,798$ & $22,828,468$ & $19,850,842$ & 1420 \\
\hline
\end{tabular}

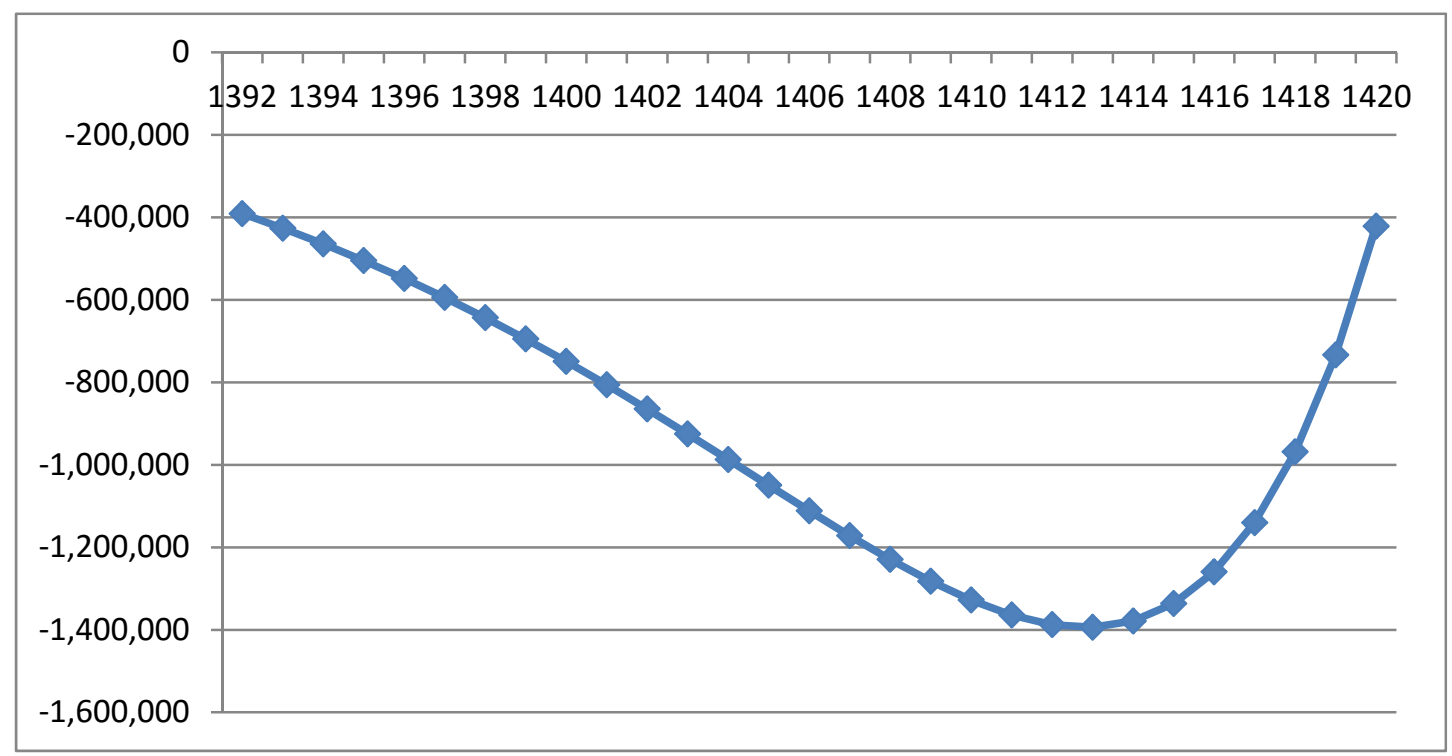

Figure 3. Predicting surplus (deficit) of pension fund of banks in the third mode

6.4 Fourth Mode: Predicting the Financial Status of the Fund at the End of Each Period by the Annual Assessment Method with Three Assumptions, including an Increase in Salaries at the Time of Employment by 13\%, an Increase in Pensions by $11 \%$, and Return on Investment by $15 \%$ with Considering the Beginning Inventory of the Fund

Table 5. Predicting surplus (deficit) of pension fund of banks in the fourth mode (Figures in Million Rials)

\begin{tabular}{|c|c|c|c|c|c|}
\hline $\begin{array}{l}\text { Surplus (deficit) at } \\
\text { beginning of the } \\
\text { periodwith } \\
\text { considering the } \\
\text { beginning inventory } \\
\text { of the Fund }\end{array}$ & $\begin{array}{c}\text { Value of } \\
\text { pension } \\
\text { deductions }\end{array}$ & $\begin{array}{l}\text { Value Income of } \\
\text { Pension Fund } \\
\text { with considering } \\
\text { investment } \\
\text { income }\end{array}$ & $\begin{array}{l}\text { Value for the } \\
\text { received } \\
\text { deduction at the } \\
\text { beginning of the } \\
\text { period }\end{array}$ & $\begin{array}{l}\text { inventory of } \\
\text { fund in the } \\
\text { first period }\end{array}$ & Financial period \\
\hline $2,289,882$ & 973,452 & $3,263,334$ & 506,341 & $2,681,042$ & 1392 \\
\hline $2,206,911$ & $1,090,266$ & $3,297,178$ & 577,229 & $2,633,365$ & 1393 \\
\hline $2,073,597$ & $1,221,098$ & $3,294,695$ & 658,041 & $2,537,948$ & 1394 \\
\hline $1,879,698$ & $1,367,630$ & $3,247,328$ & 750,166 & $2,384,636$ & 1395 \\
\hline $1,613,375$ & $1,531,746$ & $3,145,121$ & 855,190 & $2,161,653$ & 1396 \\
\hline $1,260,980$ & $1,715,555$ & $2,976,535$ & 974,916 & $1,855,381$ & 1397 \\
\hline 806,821 & $1,921,422$ & $2,728,243$ & $1,111,405$ & $1,450,127$ & 1398 \\
\hline 232,903 & $2,151,992$ & $2,384,896$ & $1,267,001$ & 927,844 & 1399 \\
\hline$-481,354$ & $2,410,231$ & $1,928,878$ & $1,444,381$ & 267,839 & 1400 \\
\hline$-1,287,229$ & $2,699,459$ & $1,412,230$ & $1,646,595$ & $-481,354$ & 1401 \\
\hline$-2,151,937$ & $3,023,394$ & 871,457 & $1,877,118$ & $-1,287,229$ & 1402 \\
\hline
\end{tabular}




$\begin{array}{lccccc}-3,077,237 & 3,386,201 & 308,965 & 2,139,915 & -2,151,937 & 1403 \\ -4,064,354 & 3,792,546 & -271,808 & 2,439,503 & -3,077,237 & 1404 \\ -5,113,817 & 4,247,651 & -866,166 & 2,781,033 & -4,064,354 & 1405 \\ -6,225,252 & 4,757,369 & -1,467,883 & 3,170,378 & -5,113,817 & 1406 \\ -7,397,140 & 5,328,254 & -2,068,887 & 3,614,231 & -6,225,252 & 1407 \\ -8,626,528 & 5,967,644 & -2,658,884 & 4,120,223 & -7,397,140 & 1408 \\ -9,908,677 & 6,683,761 & -3,224,915 & 4,697,054 & -8,626,528 & 1409 \\ -11,236,651 & 7,485,813 & -3,750,839 & 5,354,642 & -9,908,677 & 1410 \\ -12,600,826 & 8,384,110 & -4,216,716 & 6,104,292 & -11,236,651 & 1411 \\ -13,988,303 & 9,390,203 & -4,598,100 & 6,958,892 & -12,600,826 & 1412 \\ -15,382,223 & 10,517,028 & -4,865,195 & 7,933,137 & -13,988,303 & 1413 \\ -16,760,951 & 11,779,071 & -4,981,880 & 9,043,777 & -15,382,223 & 1414 \\ -18,097,119 & 13,192,560 & -4,904,560 & 10,309,905 & -16,760,951 & 1415 \\ -19,356,500 & 14,775,667 & -4,580,833 & 11,753,292 & -18,097,119 & 1416 \\ -20,496,681 & 16,548,747 & -3,947,934 & 13,398,753 & -19,356,500 & 1417 \\ -21,465,512 & 18,534,596 & -2,930,916 & 15,274,578 & -20,496,681 & 1418 \\ -22,199,288 & 20,758,748 & -1,440,540 & 17,413,019 & -21,465,512 & 1419 \\ -22,620,617 & 23,249,798 & 629,180 & 19,850,842 & -22,199,288 & 1420\end{array}$

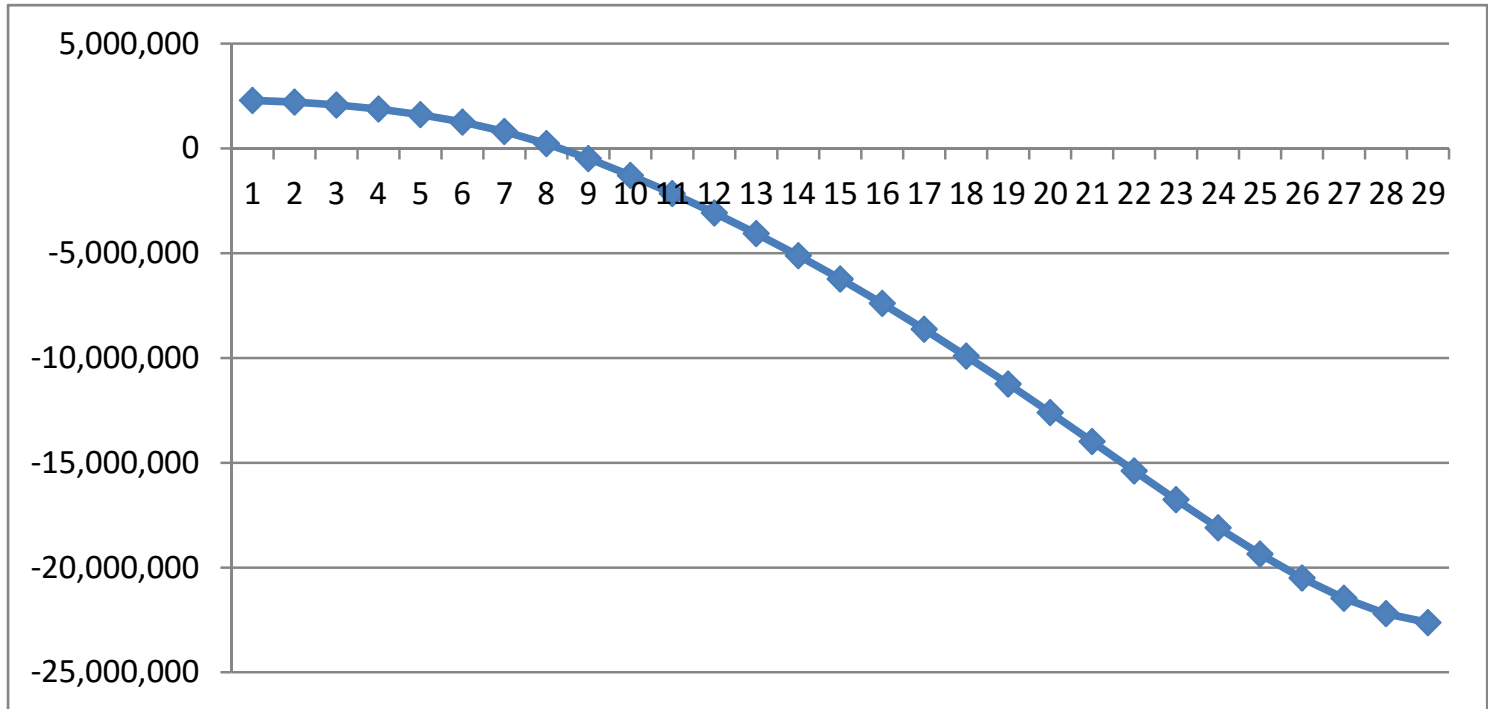

Figure 4. Predicting surplus (deficit) of pension fund of banks in the fourth mode

The results in each modepredict the deficit of the Pension Fund of banks during the studied period. Given the importance of the balance between resources and expenditures pension plans as well as the above results, some strategies are presented based on actuarial calculations for four modes.

\section{Research Results}

\subsection{Findings}

1. If the investment return rate is $17 \%$ per year,the annual growth of salaries at the time of employment is $15 \%$, and annual growth of pensions is 13\%, thefund will be faced with a deficit in 2021 .

2. If the effective rate of return increases from $17 \%$ to $21 \%$, the fund will have an appropriate status, the survival period for meeting obligations will be lifelong, and the fund will not be faced with a deficit.

3. If the investment return rate isnot possible up to $21 \%$ for the Fund and the rate is less than $21 \%$, the financial sustainability of the fund will be depleted and faced with a deficit.

4. If the investment return rate is $15 \%$ per year,the annual growth of salaries at the time of employment is $13 \%$, and annual growth of pensions is $11 \%$, thefund will be faced with a deficit in 2021 . 


\subsection{Suggestions to Cover the Deficit of Funds}

\subsubsection{Suggestions Related to the Investment of Pension Fund of Banks}

1. In order to reduce the deficit of the fund assuming an increase in salaries, it is necessary to increase the rate of return on investment,the minimum rate of return on investment fund will be about $21 \%$ to reduce the deficit and change it into a surplus of actuarial calculations.

2. For an increase in the superannuation payment up to $17 \%$ for the balance between assets and liabilities (in equilibrium), rate of return on investment of the fund will be $19 \%$.

3. Receivingthe superannuation payment and pensions for the appropriate amount at the appropriate time in terms of work experience and leniency added to increase pensions.

4. The disabled and deceased members will receive pensionsfor 20 years. Therefore, it leads to a lack of investment and increasescommitmentsof the fund.

5. Performing actuarial calculations to review and assess the financial ability of the fund for meeting future obligations for more than 5 years and review the actuarial calculations for long periods.

6. Modifying actuarial calculations in line with any change in the resources and obligations of the pension fund of banks.

Analyzing the results of the above assumptions, we find out that change the rate of return on investment is determinative for changing surplus or deficit of actuarial calculations.Perilousinvestment among different countries is different according to investment stage, investment areas, and geographic regions (Saleh Abad, 2007).

\subsubsection{Factors Affecting the Deficit of the Pension Fund of Banks}

1. Lack of attention to the Results and Suggestions actuarial reports in previous years and full disclosure of financial information related to the accounting and financial reporting prescribed in Accounting Standard 27.Therefore, it is suggested that the continuity of the pension systems is based on actuarial calculations.

2. Early retirement (less than 55 years) considering life expectancy creates additional and heavy commitments for thefund.

3. An unusual increase in superannuation payment of employees.

Considering that the pension is calculated on the basis of the last two years of service, a high percentage of theincrease in the salary increasesthe salary of the last years of service, the salaries of pensioners, and future obligations of thefund.

4. Inadequate investment in relation to the increase in salaries.

Lack of investment related to an increase in the rate of salariesis in direct contact with the inflation rate will cause the fund to be faced with deficits in the future. Lack of investment by the size of the inflation rate and also an increase in salaries in line with the inflation ratemore quickly increasethe fund commitments in comparison with the fund assets. Therefore, it causes the fund to be faced with the deficit.

\section{References}

Anantharaman, D. (2001). Actuarrial independence, client importance and pension assumptions. Rutgers Business School. Retrieved from http://andromeda.Rutgers.edu/divya

Bartel, A. L. (2007). Audit of state of Washington pension pension funding. Actuarial valuation report.

Behzadi, H. (2008). Actuarial principles and conceptsfor pension funds. Qom, Sohfi Publication.

Gerber, H. U., \& Elias, S. W. Sh. (2000). Investing for retirement: optimal capital growth and dynamic asset allocation. North American Jornal, 4, 42.

Gold, J. (2003). Accounting Bias Enables Equity Investment by D.B.p plans. Working Paper, 8.

Karen, E. L., \& Anenson, T. L. (2007). Public pension liability:why reform is necessary to save the retirement of state employees. Notre Dame jornal of low, ethics \& public lolicy.

McCrory, R. T., \& Gregory M. S. (2007). Colifornia public employees retirement system parallel valuation and certification of the actuarial valuation of the judges retirement system parallel valuation and certification of the actuarial valuation of the judges retirement system as of june, 30, 1 .

Office of the Washington state actuary. (2006). Securing to tomorrows pension today. Actuarial valuation report. 
Roghanizadeh, M. (2005). Mathematical analysis on the status of pension funds in Iran and the design of theoptimized system for the mentioned funds. Qom, Sohfi Publication.

Roghanizadeh, M. (2007). Understanding the retirement systems in the world, winter. Retrieved from http://www.isa.org.ir

Roghanizadeh, M. (2008). The challenges of the pension system. Journal of Social Security, 29(9).

Saleh Abadi, A., \& Haghighi, M. (2007). Methods of financing and investment activities of Venture Capital funds with Islamic approach (with evidence from Germany, UK and Japan). Venture Capital industry seminar, University of Tehran.

Shabahang, R. (2008). Accounting theory, Fourth Edition. Tehran: Auditing Organization Publication.

\section{Copyrights}

Copyright for this article is retained by the author(s), with first publication rights granted to the journal.

This is an open-access article distributed under the terms and conditions of the Creative Commons Attribution license (http://creativecommons.org/licenses/by/3.0/). 